\title{
Resource Brokering: Efforts to Assist Patients With Housing, Transportation, and Economic Needs in Primary Care Settings
}

Taressa K. Fraze, $P b D^{1}$

Laura B. Beidler, $M P H^{2}$

Caroline Fichtenberg, $P b D^{3}$

Amanda L. Brewster, PbD

Laura M. Gottlieb, MD, $M P H^{3}$

'Department of Family and Community Medicine, University of California, San Francisco, California

${ }^{2}$ The Dartmouth Institute for Health Policy and Clinical Practice, Geisel School of Medicine, Dartmouth College, Hanover, New Hampshire

${ }^{3}$ Department of Family and Community Medicine, Social Interventions Research \& Evaluation Network, University of California, San Francisco, California

${ }^{4}$ Division of Health Policy and Management, School of Public Health, University of California, Berkeley, California

Conflicts of interest: authors report none.

\section{CORRESPONDING AUTHOR}

Taressa K. Fraze

Department of Family and Community Medicine

University of California, San Francisco

3333 California Street, Suite 465

San Francisco, CA 94118

Taressa.Fraze@ucsf.edu

\begin{abstract}
PURPOSE Clinicians and policy makers are exploring the role of primary care in improving patients' social conditions, yet little research examines strategies used in clinical settings to assist patients with social needs.

METHODS Study used semistructured interviews with leaders and frontline staff at 29 diverse health care organizations with active programs used to address patients' social needs. Interviews focused on how organizations develop and implement case management-style programs to assist patients with social needs including staffing, assistance intensity, and use of referrals to community-based organizations (CBOs).
\end{abstract}

RESULTS Organizations used case management programs to assist patients with social needs through referrals to CBOs and regular follow-up with patients. About one-half incorporated care for social needs into established case management programs and the remaining described standalone programs developed specifically to address social needs independent of clinical needs. Referrals were the foundation for assistance and included preprinted resource lists, patient-tailored lists, and warm handoffs to the CBOs. While all organizations referred patients to $\mathrm{CBOs}$, some also provided more intense services such as assistance completing patients' applications for services or conducting home visits. Organizations described 4 operational challenges in addressing patients' social needs: (1) effectively engaging CBOs; (2) obtaining buy-in from clinical staff; (3) considering patients' perspectives; and (4) ensuring program sustainability.

CONCLUSIONS As the US health care sector faces pressure to improve quality while managing costs, many health care organizations will likely develop or rely on case management approaches to address patients' social conditions. Health care organizations may require support to address the key operational challenges.

Visual abstract

Ann Fam Med 2021;19:507-514. https://doi.org/10.1370/afm.2739.

\section{INTRODUCTION}

I $\mathrm{t}$ is increasingly clear that social factors, such as food, housing, and economic insecurity affect health outcomes. ${ }^{1-3}$ Estimates suggest that up to $80 \%$ of health outcomes are determined by social, economic, or behavioral factors. ${ }^{1}$ The emerging evidence base for social care, ${ }^{4-8}$ which refers to efforts to intervene in patients' social conditions within medical settings, ${ }^{9-13}$ coupled with the recognized impact of social adversity on health has spurred clinicians, policy makers, payers, and commercial entities to explore ways health care can better intervene in social risks of patients. ${ }^{14-22}$

Primary care practices may be especially motivated to address patients' social needs because of mounting pressure to assume responsibility for quality, utilization, and cost outcomes. ${ }^{23-26}$ Recent research suggests that primary care is responding to the increased pressure by transforming care delivery to incorporate social care. ${ }^{27,28}$ A 2017-2018 nationally representative survey of primary care physician practices found that $67 \%$ reported 
screening patients for at least 1 of 5 social needs (food, housing, utility, transportation, and interpersonal violence). ${ }^{28}$ While there is clearly interest in identifying social adversity affecting patients, we know little about how primary care practices assist patients once needs are identified.

Lessons from other primary care transformation efforts suggest primary care is likely to face barriers, including building staff capacity and ensuring leadership buy-in when incorporating social care into the practice. ${ }^{29-31}$ In this study, we interviewed a diverse, national set of health care organizations to learn about their approaches to structuring social care within primary care, the challenges they faced implementing these efforts, and how they resolved those challenges. Our goal was to gain practical insights to aid other clinicians, leaders, and policy makers as they consider approaches to addressing patients' social needs.

\section{METHODS}

\section{Design and Study Setting}

From April 19, 2019 through July 26, 2019 we conducted 33 semistructured interviews with leaders and frontline staff at health care organizations known to engage in social care. We defined social needs using the 5 key needs prioritized by the Centers for Medicare and Medicaid Services (CMS) in the Accountable Health Communities program: food insecurity, housing instability, utility needs, transportation needs, and interpersonal violence. ${ }^{32}$ All participants provided informed consent and the institutional review board at Dartmouth College approved the study.

\section{Participant Recruitment}

Sites were selected to ensure diversity in terms of ownership, structure, geography, and urbanicity. We included organizations ranging from small primary care practices to multi-state health systems. To understand the organizational-level approach to addressing social needs, we targeted managers who were responsible for developing and/or implementing programs and were identified by the organization as best suited to discuss social care activities. At some organizations, we also interviewed staff who were responsible for implementing programs when these individuals were identified as the most knowledgeable (Supplemental Table 1, available at https://www.AnnFamMed.org/lookup/ suppl/doi:10.1370/afm.2739/-/DC1 and Supplemental Table 2, https:/www.AnnFamMed.org/lookup/suppl/ doi:10.1370/afm.2739/-/DC1).

We selected sites that had active social care programs with the goal of understanding how primary care practices have structured social care activities.
Sites were identified through 2 independent samples: (1) web searches for organizations with information (eg, press releases, awards) on social care programs; and (2) a sample of systems and practices that reported screening patients for all 5 key social needs with the National Survey of Healthcare Organizations and Systems (NSHOS). ${ }^{28,33-35}$ NSHOS is a nationally representative survey of health systems and practices with 3 or more primary care physicians. ${ }^{33}$

We contacted 64 organizations (30 from web searches; 34 from NSHOS) and 29 participated (18 from web searches; 11 from NSHOS). At 4 organizations we conducted a second interview to gain additional information (Supplemental Table 2). We excluded 1 organization because their social care was limited to hospitalized patients (rather than primary care patients).

\section{Data Collection and Analysis}

Our interview guide included questions on: (1) organizational characteristics, (2) approaches to social risk screening, (3) referrals to community-based organizations (CBOs), (4) other approaches to assisting patients with social needs, and (5) interactions with CBOs (Supplemental Table 3, available at https:// www.AnnFamMed.org/lookup/suppl/doi:10.1370/ afm.2739/-/DC1). Trained qualitative researchers (T.F. and L.B.) conducted 60 -minute telephone interviews. Interviewers started with broad questions about the overall approach to social care and then tailored subsequent questions based on the programs described. Interviews were recorded and professionally transcribed.

Transcripts were first globally coded using NVivo (QSR International) by a qualitative researcher (L.B.) or a trained research assistant after intercoder reliability was established. ${ }^{36-38}$ Intercoder reliability was established by iteratively double coding transcripts and discussing discrepancies until we reached agreement. ${ }^{39}$ The codes were developed before data collection, were aligned with the interview guide domains, and were based on existing social care literature.

For this paper, we analyzed data globally coded on how organizations provided case management assistance, defined as one-on-one approaches used to help patients address social needs. To gain a deeper understanding of this area, we conducted secondary coding by iteratively sub-coding transcripts: 1 team member (L.B.) sub-coded the data, then the lead author (T.F.) reviewed the coded data, and any discrepancies were resolved with discussion. We (L.B. and T.F.) iteratively developed an analytic memo on themes observed. We used a matrix-coding approach where we justified how each organization fit within each theme. ${ }^{40}$ 


\section{RESULTS}

Organizations interviewed included 6 single-site primary care organizations, 9 multi-site organizations, 12 health systems, and 1 contracting organization that functioned similarly to a health system. Eleven of the organizations had Federally Qualified Health Centers or other community health centers. Organizations were geographically diverse: 4 in the South, 5 in the Midwest, 9 in the West, and 10 in the Northeast (Supplemental Table 2).

All organizations provided some form of case management-style assistance where a staff member helped patients access and navigate $\mathrm{CBO}$ resources. Assistance approaches required substantial organizational resources including staffing and leadership support.

\section{Models for Providing Social Needs Assistance} Embedded Models

About one-half (15 of 33) of the organizations used embedded models where they addressed patients' social needs as part of their case management or transitions programs because social needs were viewed as key barriers to achieving health outcomes:

"If there is something that is preventing a person from a good quality health, or preventing them from getting to their physician's appointments, getting to tests, getting to their medications, if they have financial difficulties...W hat we want to do is help fill those gaps." (System; organization 12; case management staff)

Embedded models typically focused on patients with complex chronic conditions, recent hospitalizations, or frequent emergency department use. Social needs assistance often relied on case management staff who were rarely trained in delivering social care. While developing clinical care plans, care managers (formally or informally) screened enrolled patients for social factors that might impact the patient's ability to meet care goals (Table 1).

\section{Standalone Models}

Standalone models (12 of 33) were designed to assist patients with social needs, regardless of their clinical needs. Patients in these programs were typically identified using a formal screening tool. Few organizations reported conducting universal social risk screening, instead they screened select patient populations such as those covered by Medicaid or in a specific geographic region. Standalone models typically used community health workers and/or social workers (Table 1).

Standalone programs, where any patient could receive assistance regardless of clinical conditions, required substantial investment from organizations. These investments highlight that efforts to address social needs were often mission driven:

"What I need to make sure is that I have a person in every building that can help people navigate through all of those resources and systems that exist both within and external to our organization. [...] Whatever it is that people need, to be able to do that is the resource brokering." (Practice; organization 21; executive leadership)

\section{Assistance Activities}

All organizations assisted patients by first providing referrals to $\mathrm{CBOs}$ and then helping patients access CBOs (Table 2). Assistance to access CBOs mainly involved tailoring referrals to ensure patients were eligible for and able to use resources. For example,

\section{Table 1. Overview of Embedded and Standalone Programs $(\mathrm{N}=27)$}

\begin{tabular}{|c|c|c|c|}
\hline \multicolumn{2}{|c|}{ Embedded Programs $(n=15)$} & \multicolumn{2}{|c|}{ Standalone Programs $(n=12)$} \\
\hline Key Features & Example Quote & Key Features & Example Quote \\
\hline $\begin{array}{l}\text { Activities to address social needs were } \\
\text { embedded within existing clinical } \\
\text { care management programs. } \\
\text { - Motivated to address needs that } \\
\text { impacted clinical care } \\
\text { - Provided referrals to CBOs } \\
\text { - Provided information, coached } \\
\text { patients, assisted with paperwork, } \\
\text { attended appointments } \\
\text { - Relied on existing care manage- } \\
\text { ment staff } \\
\text { - Patients were enrolled in care man- } \\
\text { agement due to clinical conditions } \\
\text { or recent hospitalization } \\
\text { - Social needs often identified after } \\
\text { enrollment }\end{array}$ & $\begin{array}{l}\text { "When we're monitoring } \\
\text { them, they've either } \\
\text { been uncontrolled or } \\
\text { been in the hospital } \\
\text { in the last six months, } \\
\text { so they'll either be } \\
\text { monthly or biweekly } \\
\text { calls. And when } \\
\text { they're just, multiple } \\
\text { chronics, multiple } \\
\text { hospitalizations, then } \\
\text { we want to go to } \\
\text { bimonthly or weekly } \\
\text { calls." (Practice; O14; } \\
\text { case management } \\
\text { staff) }\end{array}$ & $\begin{array}{l}\text { Focused on addressing social } \\
\text { needs independent of clinical } \\
\text { activities. } \\
\text { - Motivated to address social } \\
\text { needs because of their mission } \\
\text { - Addressed social needs } \\
\text { regardless of clinical need or } \\
\text { complexity } \\
\text { - Provided information, coached } \\
\text { patients, assisted with paper- } \\
\text { work, attended appointments } \\
\text { - Primarily staffed by commu- } \\
\text { nity health workers and social } \\
\text { workers } \\
\text { - Social needs identified via } \\
\text { screening or provider referral }\end{array}$ & $\begin{array}{l}\text { "It typically looks like a personal } \\
\text { introduction by the clinic that's serv- } \\
\text { ing the member or patient, so that } \\
\text { they're saying, 'As your care team, } \\
\text { we want to bring in [community } \\
\text { health worker] as a part of the care } \\
\text { team to be a part of our work with } \\
\text { you, and we'd really like to have her } \\
\text { come out to your home and meet } \\
\text { you or whatever you would prefer. } \\
\text { Would you be willing to engage in } \\
\text { that?' They're really trying to do a } \\
\text { warm intro and hand-off, and then } \\
\text { that person is following up through } \\
\text { whatever mechanism the patient } \\
\text { said they preferred, a phone call, a } \\
\text { text, a visit." (System; O5; executive } \\
\text { leadership) }\end{array}$ \\
\hline
\end{tabular}


health care staff regularly called $\mathrm{CBO}$ s to confirm the patient's service eligibility:

"My main focus when I call is to say, 'what are the criteria'? Because I don't want to send a patient [...] they get there and now they're missing something." (Practice; organization 14; case management staff)

About one-half (14 of 33) of the organizations assumed a coordination role between the patient and the $\mathrm{CBO}$ through activities such as scheduling appointments, helping complete paperwork, and serving as a liaison between patients and CBOs.

Organizations aimed to assist patients with the least-intensive services. Organizations differed in what they considered the lowest-intensity effective assistance: some started by providing a list of $\mathrm{CBOs}$ while others offered home visits (Table 2). In some cases, organizations provided more intense assistance and follow-up such as daily calls, accompanying patients to $\mathrm{CBO}$ appointments, and at one organization, becoming a legal representative to act on behalf of the patient:

"If that means the health guide is sitting with the patient, going to their house, helping them get paperwork, sitting with them at the Social Security Disability office waiting for the appointment and helping them present the information to the rep, then that's what they're doing." (System; organization $7_{i}$ executive leadership)

Organizations found that aligning services with patients' needs at the onset of assistance was challenging. Instead, organizations used a trial-and-error approach where case managers began with the leastintensive service they thought might be effective and then escalated as needed. As a result, most organizations did not have systematic approaches for either standardizing or calibrating service intensity with patient needs:

"They're as involved as they need to be. There are some patients that you would have to really totally walk them through the process and some that you can give the information to and they'd be able to make the calls themselves. We really try to be patient specific and responsive to what the needs are of the patient." (System ${ }_{i}$ organization $7_{i}$ program management)

\section{Social Care Approaches and Patients' Roles}

Decisions made when designing social care programs impacted the way patients were engaged (Table 3). First, an overarching difference was whether the program treated social needs as acute or chronic problems. Some programs treated social needs as limited, acute problems that interfered with health care delivery such as transportation to an appointment. Other organizations treated social needs as broader, chronic conditions such as a need for consistent transportation. Second, some organizations staff developed care plans and simply gave them to patients while others used motivational interviewing to collaboratively develop care plans with patients. Third, organizations had different views of what the responsibilities of the patient were, with some enabling patients to act independently and others partnering with patients in navigating resources. Table 4 presents potential strategies for engaging patients in program design and getting their feedback on resources.

\section{Interactions With CBOs}

Health care organizations relied on the capacity and expertise of $\mathrm{CBOs}$ to assist patients. Relationships between health care organizations and $\mathrm{CBO}$ s relied on staff-to-staff interactions to align a specific patient's care

\section{Table 2. Assistance Activities of Organizations by Intensity}

\begin{tabular}{|c|c|c|c|}
\hline $\begin{array}{l}\text { Type of } \\
\text { Assistance }\end{array}$ & Low Intensity & Medium Intensity & High Intensity \\
\hline $\begin{array}{l}\text { Range of } \\
\text { activities }\end{array}$ & $\begin{array}{l}\text { "...give them the address and infor- } \\
\text { mation to take." (Practice; O26; } \\
\text { program management) }\end{array}$ & $\begin{array}{l}\text { "...help you go through this pro- } \\
\text { cess of completing the eligibility } \\
\text { paperwork." (System; 05; execu- } \\
\text { tive leadership) }\end{array}$ & $\begin{array}{l}\text { "This was a couple that was homeless. Two of } \\
\text { the [staff] worked together and they just got } \\
\text { everything together for this couple. They got } \\
\text { them a home. They got them furnishings, } \\
\text { whatever they needed." (System; O12; case } \\
\text { management staff) }\end{array}$ \\
\hline $\begin{array}{l}\text { Interactions } \\
\text { with CBOs }\end{array}$ & $\begin{array}{l}\text { "I'll call first. Because a lot of these } \\
\text { resources, they're here one day and } \\
\text { gone the next." (Practice; 016; case } \\
\text { management staff) }\end{array}$ & $\begin{array}{l}\text { "The referral navigator may call and } \\
\text { make an appointment for them } \\
\text { right then, and really take it one } \\
\text { step further." (System; O3; pro- } \\
\text { gram management) }\end{array}$ & $\begin{array}{l}\text { "We're becoming authorized representatives, } \\
\text { which is a fancy word to say that we can } \\
\text { speak on the behalf of the patient." (System; } \\
\text { O21; case management staff) }\end{array}$ \\
\hline $\begin{array}{l}\text { Patient } \\
\text { follow-up }\end{array}$ & $\begin{array}{l}\text { "I think that when the patient pres- } \\
\text { ents again that conversation does } \\
\text { happen. Just to make sure that they } \\
\text { had the services, they're able to } \\
\text { access those services." (System; 013; } \\
\text { program management) }\end{array}$ & $\begin{array}{l}\text { "They would provide the informa- } \\
\text { tion through the mail and call } \\
\text { and be like 'Did you get this?' } \\
\text { Make sure they actually handed } \\
\text { it in." (System; O2; program } \\
\text { management) }\end{array}$ & $\begin{array}{l}\text { "Then the next step is follow-up daily to con- } \\
\text { firm that client is accessing the resources } \\
\text { identified and/or has implemented the plan." } \\
\text { (Practice; O8; program management/practic- } \\
\text { ing clinician) }\end{array}$ \\
\hline
\end{tabular}


Table 3. Organizational Approaches to Social Needs and Roles of Patients

\begin{tabular}{|c|c|c|}
\hline $\begin{array}{l}\text { Social Care } \\
\text { Approach }\end{array}$ & Organizational Approach and Example Quotes & \\
\hline \multirow{3}{*}{$\begin{array}{l}\text { Program structure } \\
\text { for treating } \\
\text { social needs }\end{array}$} & Treated as an acute condition & Treated as a chronic condition \\
\hline & $\begin{array}{l}\text { "If you have a Medicaid patient who has transportation needs } \\
\text { to health care visits. That's easy to solve. You can solve that in } \\
\text { one phone call." (System; organization 8; executive leadership) }\end{array}$ & \multirow{2}{*}{$\begin{array}{l}\text { "I'm looking at some of the patients that I'm working } \\
\text { with now and it may take several home visits or sev- } \\
\text { eral calls just to complete one task. So they will be } \\
\text { staying with you for a while. It's hard to say, but in } \\
\text { general a few months maybe." (System; organization } \\
\text { 12; case management staff) }\end{array}$} \\
\hline & $\begin{array}{l}\text { "So that to me is short-term case management. That's one, } \\
\text { maybe two visits. It's problem-solving, and then you move it } \\
\text { through." (System; organization 21; executive leadership) }\end{array}$ & \\
\hline \multirow{3}{*}{$\begin{array}{l}\text { Program design of } \\
\text { staff and patient } \\
\text { collaboration for } \\
\text { development of } \\
\text { social care plans }\end{array}$} & Health care staff drove the care plan & Patients drove the care plan \\
\hline & $\begin{array}{l}\text { "I tell them I will make a care plan for your needs." (Practice; } \\
\text { organization 16; case management staff) }\end{array}$ & \multirow{2}{*}{$\begin{array}{l}\text { "The patient may identify a different set of goals } \\
\text { than what you would have guessed looking at that } \\
\text { screener. We spend a lot of time working on moti- } \\
\text { vational interviewing and really person-centered } \\
\text { goal setting." (System; organization 8; executive } \\
\text { leadership) }\end{array}$} \\
\hline & $\begin{array}{l}\text { "She wanted her Medicaid [renewal]. But in looking over her } \\
\text { papers, we noticed that [...] she hadn't paid her taxes in I } \\
\text { don't know how many years [...]. We said, "You know what? } \\
\text { This is the most important thing. This is what's going on right } \\
\text { now." (Practice; organization 15; case management staff) }\end{array}$ & \\
\hline \multirow{3}{*}{$\begin{array}{l}\text { Extent of health } \\
\text { care organiza- } \\
\text { tions encourag- } \\
\text { ing staff to part- } \\
\text { ner with patients } \\
\text { to address social } \\
\text { needs }\end{array}$} & Patients were primarily responsible & Staff and patients were a team \\
\hline & $\begin{array}{l}\text { "It's essentially connecting them and giving them the informa- } \\
\text { tion and then it's up to the patient to contact those organiza- } \\
\text { tions and move the steps forward." (Practice; organization 1; } \\
\text { program management) }\end{array}$ & \multirow{2}{*}{$\begin{array}{l}\text { "Years ago he had lost his birth certificate. He was } \\
\text { living in his truck down by the river. [...] Our case } \\
\text { manager worked with him through an entire pro- } \\
\text { cess [...] Once that [identification] got here then she } \\
\text { assisted him to complete the housing applications } \\
\text { that he needed to complete. Once that was done } \\
\text { he actually got a house, or an apartment. Then she } \\
\text { continued to follow up with him for I think it was six } \\
\text { months. And he's doing fantastic." (Practice; organi- } \\
\text { zation 18; case management staff) }\end{array}$} \\
\hline & $\begin{array}{l}\text { "So, we try to empower our patients, and so if it's a patient who } \\
\text { either can certainly do things on their own, they just don't } \\
\text { know how to access resources, they'll teach them or talk to } \\
\text { them about what's available. They'll sit with them to make } \\
\text { phone calls if they need to." (System; organization 12; execu- } \\
\text { tive leadership) }\end{array}$ & \\
\hline
\end{tabular}

(Table 2; Table 4). Leadership-level relationships were limited. The few formal partnerships focused on specific projects, eg, providing food boxes in a clinic or providing medical care for an affordable housing project.

\section{Operational Challenges}

Social care programs required substantial staffing and financial resources. As a result, organizations struggled to balance their available resources while addressing patient needs. We identified 4 operational challenges faced when implementing social care: (1) engaging with $\mathrm{CBOs}$, (2) overcoming staff hesitancy, (3) incorporating patients' perspectives, and (4) ensuring program sustainability. Many organizations mitigated those challenges by implementing staff training, incorporating patient feedback, and establishing pragmatic goals for social care (Table 4).

\section{DISCUSSION}

As pressure mounts for primary care practices to consider patients' social conditions, our study highlights how many health care organizations are engaging in social care. ${ }^{27,28}$ This level of engagement may reflect the growth in external facilitators for primary care initiatives related to patients' social conditions. $16,17,19,20,41,42$ Approximately one-half of the organizations incorporated social care into existing case management programs targeted to clinically complex patients. The remaining organizations developed standalone programs that provided social needs assistance independently from clinical needs. Regardless of the model, social care activities were similar and required substantial investment and strong leadership.

It is not surprising that one-half of the organizations delivered social care as part of their effort to improve health outcomes for complex patients since delivering comprehensive, coordinated care for these patients is a cornerstone of primary care. ${ }^{43,44}$ Similarly, federal policymakers have focused on improving the social conditions of clinically complex patients, ${ }^{32,45-47}$ which is not unexpected as the links between health care outcomes, costs, and social conditions are likely strongest for these patients. ${ }^{48,49}$ For example, as part of the CHRONIC Care Act, the CMS granted Medicare Advantage plans greater flexibility in supplemental benefits. ${ }^{45-47,50}$ The transition toward value-based care and total costs of care, emphasizes patients for whom health care costs can be reduced the most. . $^{32,51-53}$

More surprising is that nearly one-half of the organizations launched programs that were independent from clinical activities. This may indicate an increasing acceptance of assuming responsibility for whole person care, that encompasses social and clinical needs. In these organizations, patients with minimal clinical needs could access support for their social conditions. The costs associated with assisting patients who are 
Table 4. Operational Challenges and Strategies Used to Mitigate Them

\begin{tabular}{|c|c|c|c|}
\hline Operational Challenges & Example of Challenge & $\begin{array}{l}\text { Example of How Challenge } \\
\text { was Managed }\end{array}$ & Strategies ${ }^{a}$ \\
\hline $\begin{array}{l}\text { Engaging CBOs } \\
\text { - Referrals require interac- } \\
\text { tion with CBOs } \\
\text { - CBOs may have capacity } \\
\text { challenges } \\
\text { - CBOs may want a role in } \\
\text { developing programs } \\
\text { - CBOs may work with } \\
\text { multiple health care } \\
\text { organizations }\end{array}$ & $\begin{array}{l}\text { "We also have [...] a large health } \\
\text { system in our region, and they } \\
\text { are also implementing [referral } \\
\text { platform]. However, they've } \\
\text { rebranded theirs [website } \\
\text { name] and so they've caused } \\
\text { a little bit of confusion in the } \\
\text { community." (Organization 3; } \\
\text { program management) }\end{array}$ & $\begin{array}{l}\text { "We did a survey of our community } \\
\text { organizations and asked them } \\
\text { what it was like to work with } \\
\text { health systems. And they found } \\
\text { that there were three major } \\
\text { issues...." (Organization 23; execu- } \\
\text { tive leadership) }\end{array}$ & $\begin{array}{l}\text { - Engage with CBOs early when } \\
\text { developing programs that rely } \\
\text { on their services or expertise } \\
\text { - If choosing a platform, ensure } \\
\text { CBO buy-in before purchasing } \\
\text { - Foster both leader-to-leader } \\
\text { and staff-to-staff relationships } \\
\text { between health care organiza- } \\
\text { tion and CBOs }\end{array}$ \\
\hline $\begin{array}{l}\text { Buy-in among clinical staff } \\
\text { - Nurses, medical assistants, } \\
\text { and physicians are often } \\
\text { not trained in social care } \\
\text { - Staff may already feel } \\
\text { overwhelmed }\end{array}$ & $\begin{array}{l}\text { "Before we started our commu- } \\
\text { nity health worker program our } \\
\text { nurses and social workers [...] } \\
\text { were struggling to work at the } \\
\text { top of their license. [...] they } \\
\text { had at first try to deal with the } \\
\text { social determinants." (Organiza- } \\
\text { tion 12; executive leadership) }\end{array}$ & $\begin{array}{l}\text { "It's training somebody up and it } \\
\text { has to be somebody who just has } \\
\text { that knack. They're compassion- } \\
\text { ate, they can just connect with the } \\
\text { patient, build rapport. It's harder } \\
\text { than you think..." (Organization 6; } \\
\text { program management) }\end{array}$ & $\begin{array}{l}\text { - Train staff to deliver assistance } \\
\text { that is culturally competent } \\
\text { and is sensitive to patients' } \\
\text { experiences } \\
\text { - Assign staff with skills in } \\
\text { motivational interviewing, } \\
\text { emotional intelligence, and } \\
\text { community navigation }\end{array}$ \\
\hline $\begin{array}{l}\text { Patients' perspectives } \\
\text { - Some patients may not } \\
\text { want assistance } \\
\text { - Patients may prioritize } \\
\text { needs differently } \\
\text { - Patients may have existing } \\
\text { relationships with CBOs }\end{array}$ & $\begin{array}{l}\text { "Why they will follow up with } \\
\text { us and why they will not [...]. } \\
\text { We've got these wonderful pro- } \\
\text { grams, and people screen posi- } \\
\text { tive for something, why don't } \\
\text { they want to do something } \\
\text { about that?" (Organization 24; } \\
\text { executive leadership) }\end{array}$ & $\begin{array}{l}\text { "'Would you like help? Would you } \\
\text { like me to meet with you? Would } \\
\text { you like some assistance working } \\
\text { on some of these challenges' and } \\
\text { then engage in a relationship with } \\
\text { that patient to establish patient } \\
\text { goals and then to create some } \\
\text { plans to meet those goals." (Orga- } \\
\text { nization 8; executive leadership) }\end{array}$ & $\begin{array}{l}\text { - Engage patients when develop- } \\
\text { ing programs } \\
\text { - Patients can provide input into } \\
\text { available resources and experi- } \\
\text { ences using resources } \\
\text { - Engage patients in defining } \\
\text { goals, providing assistance, and } \\
\text { prioritizing referrals to CBOs }\end{array}$ \\
\hline $\begin{array}{l}\text { Program sustainability } \\
\text { - How to measure success? } \\
\text { - Organizational commit- } \\
\text { ment for short-term versus } \\
\text { long-term }\end{array}$ & $\begin{array}{l}\text { "So having that capability [social } \\
\text { worker] in house has made a } \\
\text { huge difference, even though } \\
\text { it's not necessarily remuner-- } \\
\text { ated, which is a problem." } \\
\text { (Organization 28; practicing } \\
\text { clinician) }\end{array}$ & $\begin{array}{l}\text { "I think the key thing is how do we } \\
\text { pay for this. I think that's got to } \\
\text { be on the top of everyone's list } \\
\text { right now. We're paying for all } \\
\text { of that. What's the return on that } \\
\text { investment? I don't know." (Orga- } \\
\text { nization 8; executive leadership) }\end{array}$ & $\begin{array}{l}\text { - Establish goals for the program } \\
\text { before starting } \\
\text { - Organizations with fewer } \\
\text { resources may choose embed- } \\
\text { ded programs which typically } \\
\text { rely on existing staff }\end{array}$ \\
\hline
\end{tabular}

not clinically complex are likely steep: efforts are less likely to be reimbursed ${ }^{54}$ dedicated staff are needed if care teams are already overburdened, ${ }^{55,56}$ and substantial capital may be needed to achieve buy-in across leadership and clinical teams. ${ }^{57,58}$

One of the factors that impacted how organizations assisted patients seemed driven by the underlying perception of patients' responsibility. Some organizations focused on giving patients the tools needed to solve their problems (ie, referring to $\mathrm{CBOs}$, limited assistance), and having the patient assume responsibility for implementing their care plan. This approach involves several assumptions and illustrates 1 of the 4 operational challenges organizations experiencedhow to incorporate patients' perspectives. First, it assumes information given to the patient is valuable. However, the patient may have already engaged with the $\mathrm{CBO}$, may not qualify for services, or services may be inadequate. Second, it assumes that health care organizations know what is best for patients. When a health care organization makes a care plan-clinical or social-for a patient with little input from the patient, that plan may not reflect and prioritize the patients' needs, values, and goals. Third, it assumes the patient can enact the care plan when there are likely barriers. By not using patients as experts, health care organizations may be missing out on useful and impactful knowledge that could make programs more effective.

In addition to the struggle to incorporate patients' perspectives into social care programs, we identified 3 other operational challenges along with practical approaches to managing those challenges. First, referrals and assistance strategies rely on CBOs, yet few organizations substantively involved $\mathrm{CBO}$ s in planning and implementation. Health care organizations should collaborate and engage with local CBOs early when developing programs that rely on $\mathrm{CBO}$ expertise. Second, health care organizations were surprised that clinical staff were often hesitant because social care may feel out of their scope or they may already 
feel overwhelmed with their responsibilities. At a time when there is focus on burnout within primary care, not just for physicians, ${ }^{59-62}$ it is important to build buyin for social needs programs across all levels of the organization. Finally, few organizations had clear plans to ensure programs were sustainable.

Our study has key limitations. First, our study cannot be generalized to all health care organizations. Our findings can provide information on how some organizations consider social conditions in clinical settings. Our data reflect the perspectives of leaders, managers, and frontline staff which could impact our findings. Additionally, our study does not evaluate the impacts of efforts to deliver social care.

Our study offers an overview of approaches, and identifies potential pitfalls, for health care organizations considering how to deliver social care. Guidance is especially needed given the emphasis on the impact of social adversity by influential stakeholders, including the National Academy of Medicine ${ }^{19}$ and the United States Preventive Services Taskforce, ${ }^{19,20}$ and will likely spur further commitment by health care organizations to deliver social care.

\section{To read or post commentaries in response to this article, go to https://www.AnnFamMed.org/content/19/6/507/tab-e-letters.}

Key words: case management; primary care; social determinants of health Submitted October 6, 2020; submitted, revised, March 14, 2021; accepted April 13, 2021.

Funding support: Support for this research was provided, in part, by the Robert Wood Johnson Foundation (Grant IDs: 75770, 75992) and, in part, by AHRQ's Comparative Health System Performance Initiative under Grant \# 1U19HS024075, which studies how health care delivery systems promote evidence-based practices and patient-centered outcomes research in delivering care. The views expressed here do not necessarily reflect the views of the Robert Wood Johnson Foundation or AHRQ.

Previous presentations: A portion of this manuscript was presented at the AcademyHealth Annual Research Meeting; June 2, 2019; Washington, DC.

Acknowledgments: The authors would like to thank Hannah Lang for her assistance with coding and data analysis.

Supplemental materials: Available at https://www.AnnFamMed. org/lookup/suppl/doi:10.1370/afm.2739/-/DC1.

\section{References}

1. Hood CM, Gennuso KP, Swain GR, Catlin BB. County health rankings: relationships between determinant factors and health outcomes. Am J Prev Med. 2016;50(2):129-135. 10.1016/j.amepre.2015.08.024

2. Liaw W, Krist AH, Tong ST, et al. Living in "Cold Spot" communities is associated with poor health and health quality. J Am Board Fam Med. 2018;31(3):342-350. 10.3122/jabfm.2018.03.170421

3. Knighton AJ, Stephenson B, Savitz LA. Measuring the effect of social determinants on patient outcomes: a systematic literature review. J Health Care Poor Underserved. 2018;29(1):81-106. 10.1353/ hpu.2018.0009

4. Berkowitz SA, Hulberg AC, Hong C, et al. Addressing basic resource needs to improve primary care quality: a community collaboration programme. BMJ Qual Saf. 2016;25(3):164-172. 10.1136/ bmjas-2015-004521
5. Gottlieb LM, Wing H, Adler NE. A systematic review of interventions on patients' social and economic needs. Am J Prev Med. 2017; 53(5):719-729. 10.1016/j.amepre.2017.05.011

6. Viswanathan M, Kraschnewski JL, Nishikawa B, et al. Outcomes and costs of community health worker interventions: a systematic review. Med Care. 2010;48(9):792-808. 10.1097/MLR.0b013e3181 e35b51

7. Wortman Z, Tilson EC, Cohen MK. Buying health for North Carolinians: addressing nonmedical drivers of health at scale. Health Aff (Millwood). 2020;39(4):649-654.

8. Gottlieb L, Tobey R, Cantor J, Hessler D, Adler NE. Integrating social and medical data to improve population health: opportunities and barriers. Health Aff (Millwood). 2016;35(11):2116-2123. 10. 1377/hlthaff.2016.0723

9. Cornell PY, Halladay CW, Ader J, et al. Embedding social workers in veterans health administration primary care teams reduces emergency department visits. Health Aff (Millwood). 2020;39(4):603-612. 10.1377/hlthaff.2019.01589

10. DeVoe JE, Bazemore AW, Cottrell EK, et al. Perspectives in primary care: a conceptual framework and path for integrating social determinants of health into primary care practice. Ann Fam Med. 2016; 14(2):104-108. 10.1370/afm.1903

11. Gottlieb L, Fichtenberg C, Alderwick H, Adler N. Social determinants of health: what's a healthcare system to do? J Healthc Manag. 2019;64(4):243-257. 10.1097/JHM-D-18-00160

12. Gurewich D, Garg A, Kressin NR. Addressing social determinants of health within healthcare delivery systems: a framework to ground and inform health outcomes. J Gen Intern Med. 2020;35(5):15711575. 10.1007/s11606-020-05720-6

13. Steiner JF, Bellows J, Banegas MP, Gottlieb LM. Interventions to address basic resource needs in Kaiser Permanente: a care continuum and an outcomes wheel. Perm J. 2018;22:18-130. 10.7812/ TPP/18-130

14. American Academy of Family Physicians. Social determinants of health (SDoH): family physicians' role. Published 2018. Accessed Apr 5, 2019. https://www.aafp.org/dam/AAFP/documents/patient_ care/everyone_project/sdoh-survey-results.pdf

15. Bogard K, Murray V. C. A, eds. Perspectives on Health Equity and Social Determinants of Health. National Academy of Medicine; 2017.

16. Byhoff E, Kangovi S, Berkowitz SA, et al; Society of General Internal Medicine. A Society of General Internal Medicine Position Statement on the internists' role in social determinants of health. J Gen Intern Med. 2020;35(9):2721-2727. 10.1007/s11606-020-05934-8

17. Castrucci $B$, Auerbach J. Meeting individual social needs falls short of addressing social determinants of health. Health Affairs blog. January 16, 2019. https://www.healthaffairs.org/do/10.1377/ hblog20190115.234942/full

18. Hagan JF, Shaw JS, Duncan PM, eds. Bright Futures: Guidelines for Health Supervision of Infants, Children, and Adolescents. American Academy of Pediatrics; 2017; No. 4.

19. National Academies of Sciences, Engineering, and Medicine. Integrating Social Care into the Delivery of Health Care: Moving Upstream to Improve the Nation's Health. The National Academies Press; 2019.

20. Davidson KW, Kemper AR, Doubeni CA, et al. Developing primary care-based recommendations for social determinants of health: methods of the U.S. Preventive Services Task Force. Ann Intern Med. 2020;173(6):461-467. 10.7326/M20-0730

21. Daniel H, Bornstein SS, Kane GC, et al; Health and Public Policy Committee of the American College of Physicians. Addressing social determinants to improve patient care and promote health equity: an American College of Physicians position paper. Ann Intern Med. 2018;168(8):577-578. 10.7326/M17-2441

22. Kangovi S, Mitra N, Grande D, Long JA, Asch DA. Evidence-based community health worker program addresses unmet social needs and generates positive return on investment. Health Aff (Millwood). 2020;39(2):207-213. 10.1377/hlthaff.2019.00981 
23. Bodenheimer T, Pham HH. Primary care: current problems and proposed solutions. Health Aff (Millwood). 2010;29(5):799-805. 10. 1377/hlthaff.2010.0026

24. Bodenheimer TS, Smith MD. Primary care: proposed solutions to the physician shortage without training more physicians. Health Aff (Millwood). 2013;32(11):1881-1886. 10.1377/hlthaff.2013.0234

25. Siddiqui M, Berkowitz SA. Shared savings models for ACOs-incentivizing primary care physicians. J Gen Intern Med. 2014;29(6):832-834. 10.1007/s11606-013-2733-5

26. VanLare JM, Conway PH. Value-based purchasing-national programs to move from volume to value. [published correction appears in N Engl J Med. 2012;367(21):2060]. N Engl J Med. 2012;367(4): 292-295. 10.1056/NEJMp1204939

27. Cartier Y, Gottlieb L. The prevalence of social care in US health care settings depends on how and whom you ask. BMC Health Serv Res. 2020;20(1):481. 10.1186/s12913-020-05338-8

28. Fraze TK, Brewster AL, Lewis VA, Beidler LB, Murray GF, Colla $\mathrm{CH}$. Prevalence of screening for food insecurity, housing instability, utility needs, transportation needs, and interpersonal violence by US physician practices and hospitals. JAMA Netw Open. 2019;2(9): e1911514. 10.1001/jamanetworkopen.2019.11514c

29. Farmer MM, Rose DE, Rubenstein LV, et al. Challenges facing primary care practices aiming to implement patient-centered medical homes. J Gen Intern Med. 2014;29 Suppl 2(Suppl 2):S555-S562. 10.1007/s11606-013-2691-y

30. Levesque JF, Haggerty JL, Hogg W, et al. Barriers and facilitators for primary care reform in Canada: Results from a deliberative synthesis across five provinces. Healthc Policy. 2015;11(2):44-57.

31. O'Malley AS, Gourevitch R, Draper K, Bond A, Tirodkar MA. Overcoming challenges to teamwork in patient-centered medical homes: a qualitative study. J Gen Intern Med. 2015;30(2):183-192.

32. Alley DE, Asomugha CN, Conway PH, Sanghavi DM. Accountable health communities-addressing social needs through Medicare and Medicaid. N Engl J Med. 2016;374(1):8-11. 10.1056/NEJMp1512532

33. About NSHOS. Accessed May 6, 2019. https://sites.dartmouth.edu/ coe/nshos/

34. Fraze TK, Beidler LB, Briggs ADM, Colla CH. 'Eyes in the home': ACOs use home visits to improve care management, identify needs, and reduce hospital use. Health Aff (Millwood). 2019;38(6):10211027. 10.1377/hlthaff.2019.00003

35. King AC, Schwartz LM, Woloshin S. A national survey of the frequency of drug company detailing visits and free sample closets in practices delivering primary care. JAMA Intern Med. 2020;180(4): 592-595.

36. NVivo for Mac [computer program]. 2014.

37. Glaser BG, Strauss AL. The Discovery of Grounded Theory: Strategies for Qualitative Research. Routledge; 2017.

38. Corbin J, Strauss AL. Basics of Qualitative Research: Techniques and Procedures for Developing Grounded Theory. 3rd ed. Sage Publications, Inc; 2008.

39. Miles M, Huberman A, Saldana J. Qualitative Data Analysis: A Sourcebook of New Methods. Thousand Oaks, CA: Sage; 2014.

40. Scott KW, Howell D. Clarifying analysis and interpretation in grounded theory: Using a conditional relationship guide and reflective coding matrix. Int J Qual Methods. 2008;7(2):1-15. 10.1177/160940690800700201

41. Eisenson H, Mohta Namita S. Health care organizations can and must incorporate social determinants. NEJM Catal. 2020;1(3). 10.1056/CAT.20.0130

42. Maani N, Galea S. The role of physicians in addressing social determinants of health. JAMA. 2020;323(16):1551-1552.

43. Miller AM, Swartwout KD, Schoeny ME, Vail M, McClenton R. Care coordination to target patient complexity and reduce disparities in primary care. Public Health Nurs. 2019;36(4):451-460. 10.1111/phn. 12606
44. Peterson K, Anderson J, Bourne D, et al. Health care coordination theoretical frameworks: a systematic scoping review to increase their understanding and use in practice. J Gen Intern Med. 2019; 34(Suppl 1):90-98. 10.1007/s11606-019-04966-z

45. Thomas KS, Durfey SNM, Gadbois EA, et al. Perspectives of Medicare Advantage plan representatives on addressing social determinants of health in response to the CHRONIC Care Act. JAMA Netw Open. 2019;2(7):e196923. 10.1001/jamanetworkopen.2019.6923

46. Tumlinson A, Burke M, Alkema G. The CHRONIC Care Act of 2018: advancing care for adults with complex needs. Published 2018. https://www thescanfoundation org/sites/default/files/chronic_care_ act_brief_030718_final pdf

47. Willink A, DuGoff EH. Integrating medical and nonmedical servicesthe promise and pitfalls of the CHRONIC Care Act. N Engl J Med. 2018;378(23):2153-2155.

48. Cockerham WC, Hamby BW, Oates GR. The social determinants of chronic disease. Am J Prev Med. 2017;52(1S1):S5-S12. 10.1016/j. amepre.2016.09.010

49. Wammes JJG, van der Wees PJ, Tanke MAC, Westert GP, Jeurissen PPT. Systematic review of high-cost patients' characteristics and healthcare utilisation. BMJ Open. 2018;8(9):e023113. 10.1136/ bmjopen-2018-023113

50. Creating high-quality results and outcomes necessary to improve Chronic (CHRONIC) Care Act of 2017, S.870 (2017).

51. Fraze T, Lewis VA, Rodriguez HP, Fisher ES. Housing, transportation, and food: how ACOs seek to improve population health by addressing nonmedical needs of patients. Health Aff (Millwood). 2016; 35(11):2109-2115. 10.1377/hlthaff.2016.0727

52. Hsu J, Price M, Vogeli $C$, et al. Bending the spending curve by altering care delivery patterns: the role of care management within a pioneer ACO. Health Aff (Millwood). 2017;36(5):876-884. 10.1377/ hlthaff.2016.0922

53. McCarthy D, Ryan J, Klein S. Models of care for high-need, highcost patients: an evidence synthesis. Issue Brief (Commonw Fund). 2015;31:1-19.

54. Bachrach D, Pfister H, Wallis K, Lipson M. Addressing Patients' Social Needs: An Emerging Business Case for Provider Investment. The Commonwealth Fund; 2014.

55. Dyrbye LN, West CP, Burriss TC, Shanafelt TD. Providing primary care in the United States: the work no one sees. Arch Intern Med. 2012;172(18):1420-1421.

56. O'Malley PG. First things first: getting primary care right. JAMA Intern Med. 2013;173(1):13-14. 10.1001/jamainternmed.2013.1124

57. Bleser WK, Miller-Day M, Naughton D, Bricker PL, Cronholm PF, Gabbay RA. Strategies for achieving whole-practice engagement and buy-in to the patient-centered medical home. Ann Fam Med. 2014;12(1):37-45. 10.1370/afm.1564

58. Lau R, Stevenson F, Ong BN, et al. Achieving change in primary care-causes of the evidence to practice gap: systematic reviews of reviews. Implement Sci. 2016;11:40. 10.1186/s13012-016-0396-4

59. Olayiwola JN, Willard-Grace R, Dubé K, et al. Higher perceived clinic capacity to address patients' social needs associated with lower burnout in primary care providers. J Health Care Poor Underserved. 2018;29(1):415-429. 10.1353/hpu.2018.0028

60. Rabatin J, Williams E, Baier Manwell L, Schwartz MD, Brown $\mathrm{RL}$, Linzer M. Predictors and outcomes of burnout in primary care physicians. J Prim Care Community Health. 2016;7(1):41-43. 10.1177/2150131915607799

61. Weiner JZ, McCloskey JK, Uratsu CS, Grant RW. Primary care physician stress driven by social and financial needs of complex patients. J Gen Intern Med. 2019;34(6):818-819. 10.1007/s11606-018-4815-x

62. Willard-Grace R, Hessler D, Rogers E, Dubé K, Bodenheimer T, Grumbach K. Team structure and culture are associated with lower burnout in primary care. J Am Board Fam Med. 2014;27(2):229-238. 10.3122/jabfm.2014.02.130215 